\title{
„PROJECT SERPO”: A MÉDIAMANIPULÁCIÓ EXTRÉM ESETE
}

\author{
Szerző: \\ Mező Lilla Dóra \\ Eötvös Loránd Tudomáynegyetem
}

Szerző e-mail címe:

dori.mezo1@gmail.com

\section{Lektorok:}

Harai Dénes (PhD, CSc)
Nemzeti Közszolgálati Egyetem

Kenyeres Attila Zoltán $(\mathrm{PhD})$

Debreceni Egyetem

...és további két anonim lektor

\begin{abstract}
Absztrakt
A híres roswelli repülő csészealj szerencsétlenségből létrejött egy Project Serpo nevezetű csillagközi csereprogram. Legenda ez vagy valóság? A média szerint, egyrészt több kutató, tiszt és kormányalkalmazott állítja a Project Serpo létezését, míg más kutatók, tisztek, kormány-alkalmazottak tagadják azt. Az is valószínűsíthető, hogy a program bizonyos, űrlényeket és csillagközi utazást nélkülöző formában valóban létrejött, ám a média révén közreadott (félreértéseken alapuló vagy tudatos) félretájékoztatás következtében a Project Serpo legenda „önálló életre kelt”. A történet a média és a média-manpipulátorok közvéleményt befolyásoló szerepére is rávilágít.
\end{abstract}

Kulcsszavak: pszichológia, hadviselés

Diszciplinák: pszichológia, hadtudomány, médiatudomány

\begin{abstract}
'PROJECT SERPO': AN EXTREME CASE OF MANIPULATION OF MEDIA

The famous Roswell flying saucer disaster resulted in an interstellar exchange project called Project Serpo. Is this a legend or a reality? According to the media, on the one hand, several researchers, officers and government employees claim the existence of Project Serpo, while other researchers, officers and government employees deny it. It is also probable that the program was created in some form without space and interstellar travel, but the misinformation (based on misunderstanding or consciousness) published through the media made Project Serpo legend 'come to life'. The story is also noteworthy because it highlights the role of the media and media manipulators in influencing public opinion.
\end{abstract}

Keywords: psychology, warfare

Discipline: psychology, military science, media science

Mező Lilla Dóra (2020): „Project Serpo”: a médiamanipuláció extrém esete. Lélektan és hadviselés - interdiszciplináris folyóirat, II. évf. 2020/1. szám. 67-77. doi: 10.35404/LH.2020.1.67 
A „Project Serpo”: 12 amerikai ûrhajós útja egy földön kívüli civilizáció bolygójára, egy földön kívüliekkel végzett csereprogram keretében. Újságcikkek, tanulmányok, könyvek, weboldalak (serpo.org) jöttek létre e projekttel kapcsolatban, s a Mirage Men című dokumentumfilmet is leforgatták. A „Project Serpo”: egy modern legenda, ami talán csak egyetlen médiamanipulátornak köszönhető...

\section{Előzmények}

A Project Serpo története 1947-ben kezdődött, amikor a The Sacramento Bee (1947), illetve a Roswell Daily Record (1947) újságok július 8-ai számának hasábjain a következő című híradások jelentek meg (1. ábra):

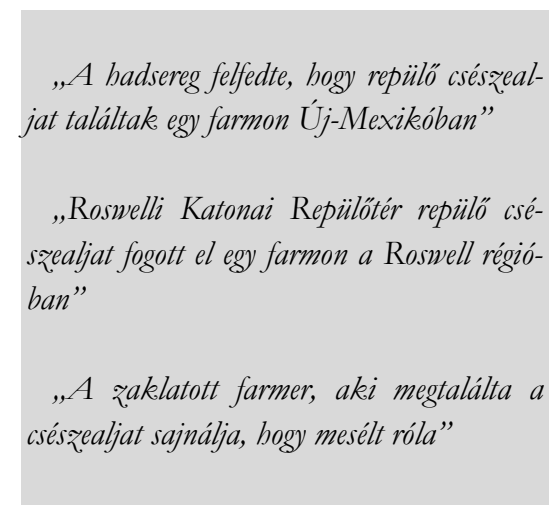

A híradások szerint földönkívüli űrhajó zuhant le William Brazel farmján, melynek maradványait a hadsereg azonnal lefoglalta (Roswell Daily Record, 1947). Az a hír is szárnyra kelt, hogy valójában nem egy, hanem két szerencsétlenség is történt. E verzió szerint az egyik űrhajó az

1. ábra: a The Sacramento Bee és a Roswell Daily Record újságok 1947. július 8.-i hírei (forrás: The Sacramento Bee, 1947; Roswell Daily Record, 1947)

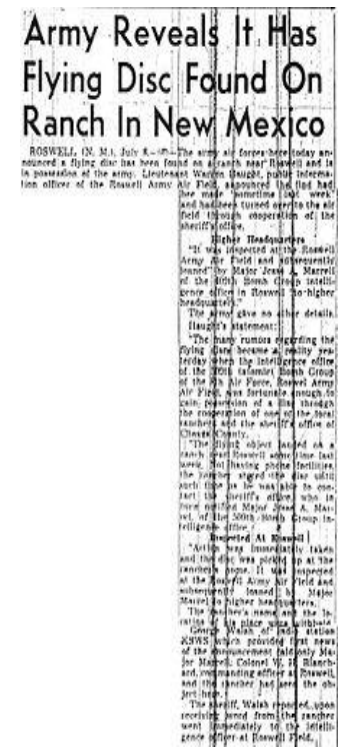

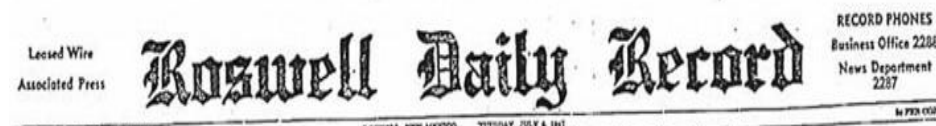

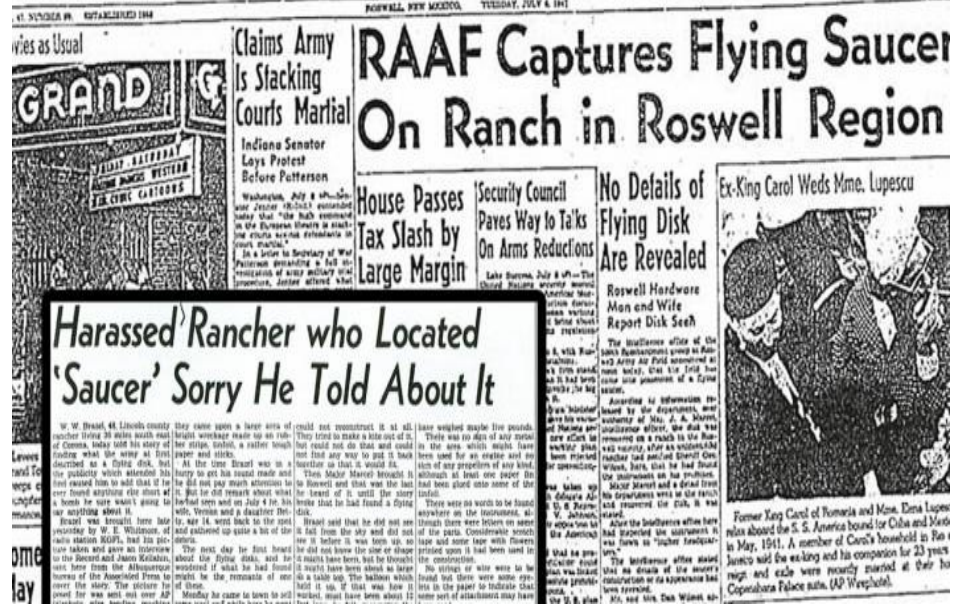


amerikai Corona városának dél-nyugati részén, a másik pedig Datil déli részén zuhant le (Birnes, 2006; Doty, 2006). A katasztrófák következtében minden idegen (a következőkben: EBE, Extraterrestrial Biological Entity) meghalt - egy kivételével, akit a Los Alamos Laboratóriumba szállítottak, ahol 1952-ig élt. Az anyabolygójával többször is próbálta ugyan ezalatt az idő alatt felvenni a kapcsolatot, társai azonban csak halála után érkeztek meg a Földre (Pilkington, 2006; Swartz, 2007; Gaia, 2017).

Látható, hogy nem fantáziaszegény személyek állnak a „Project Serpo”-t megalapozó történet hátterében. $A$, mitosżteremtô" fantária müködése mégis a „Poject Serpo”ban bontakozik ki igazán.

\section{A „Project Serpo”}

A történet szerint, az idegenek a körülbelül 40 fényévre található Zeta Reticuli csillagrendszer Serpo bolygójáról jöttek (Kasten, 2007 - v.ö.: 2. ábra). A „Project Serpo" (Serpo Projekt) keretében 12 amerikai katonát küldtek e bolygóra egy csereprogram keretében 1965 és 1978 között, miután részt vettek az űrhajósokat felkészítő általános kiképző programban (Jack Caseyre hivatkozik: Doty, 2006). Doty (2006 hivatkozik McGovern-re) szerint, noha sokan hiszik, hogy tíz férfi és két nő vett rész a programban, ez nem lehetséges, hiszen akkoriban a nők szerepe a hadseregben még nem volt olyan erőteljes, hogy kiválasszák őket egy ilyen küldetésre. A legenda szerint a kiválasztott 12
2. ábra: Len Kasten könyve a Project Serporól (forrás: Kasten, 2013)

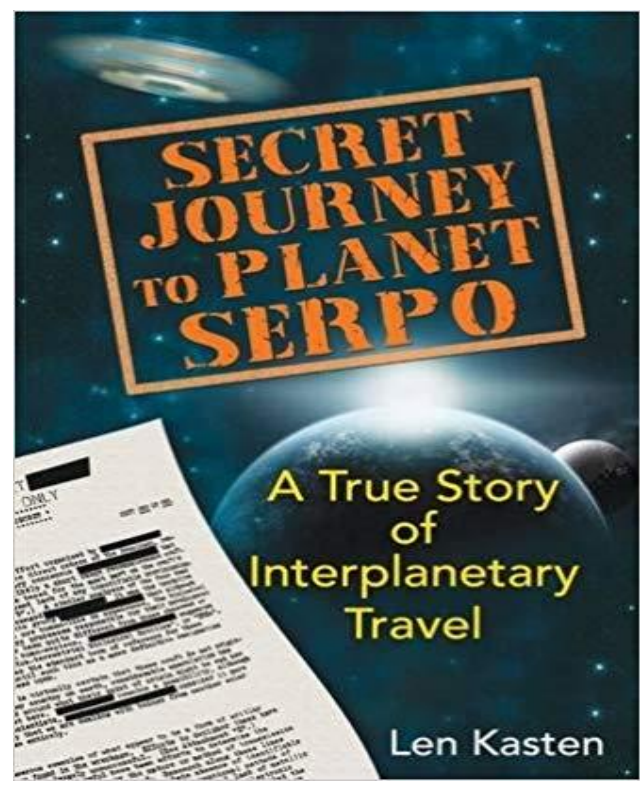

férfinak olyan előélettel kellett rendelkeznie, hogy eltűnhessenek 10 évre anélkül, hogy bárki keresné őket. A csillagközi út mindössze 10 hónapig tartott ugyan, ám maga a küldetés 13 évig elhúzódott a Serpo bolygó kettőscsillaga miatt. Az egyik asztronauta még az odafelé vezető úton meghalt egy balesetben, egy másik utazó a sugárzás miatt halt meg, ketten pedig úgy döntöttek, hogy a Serpon maradnak (róluk azóta sincs hír). A küldetésről így csak nyolcan tértek vissza, és egy évig karanténban tartották őket megfigyelés alatt (Swartz, 2007; Gaia, 2017).

A történetbeli, visszatért űrhajósok beszámolója alapján a Serpo bolygó átmérōje kisebb, mint a Földé. Két napja miatt sosincs teljesen sötét a felszínén, így az az 
az idő múlását is nehezebb követni. A legendabeli résztvevők szerint más fizikai törvények érvényesek ott, mint amit a bolygónkon ismerünk. A 650000 föt számláló EBE-k kisebb közösségekben élnek.

\section{Összehasonlításként:}

A Serpo bolygó lakossága (Kasten, 2007): 650000 fö

A Föld lakossága 1978-ban (Net1): kb. 4000000000 fö

A Föld lakossága 2020 év elején (Net1): több mint 7700000000 fö

Az ENSZ Demográfiai Évkönyve (hivatkozik rá: Net2) által használt településhierarchia szerint 500 000-1 000000 fő között nagyvárosról 1 millió fő felett metropolisról beszélünk.

A mítosz további elemei: a Serpo bolygó értelmes lényeinek technológiája sokkal fejlettebb, mint a miénk, ehhez képest azonban civilizációjuk jóval elmaradottabb, ami elég érdekes kontrasztot jelent. Ételeik minden túlélő szerint ehetetlenek, papír ízűek voltak, amit sosem tudtak megszokni. Maguk a földönkívüliek egyébként nagyon kedvesek, vendégszeretőek voltak. Az asztronauták visszatérése óta nem tudunk róla, hogy sikerült-e újra felvenni a kapcsolatot az EBE-kel. Az utolsó túlélő 2002-ben hunyt el (Pilkington, 2006; Kasten, 2007, 2013; Gaia, 2017).
A „Project Serpo” előzményei és közvetlen története nagyjából a fentiek alapján foglalhatók össze. E legendának azonban fordulatokban ugyancsak gazdag „utóélete” is van.

\section{A legenda folytatódik}

Tanulságos áttekinteni, hogy a történet előzményében már említett sajtóforrásokon kívül milyen egyéb forrásokra hivatkozva alakult tovább a „Project Serpo” mítosza.

Érdekes figyelemmel kísérni, ahogy egy témával kapcsolatban, hol hiteles, hol kevésbé hiteles hírforrások, hol hiteles, hol kevésbé híteles hírei egymással összefüggésbe hozva, olykor újabb motivumokat hozzáadva alakítják a történetet, s ezzel együtt (a médián keresztül) a közvéleményt. Az elszeparált információmorzsák közötti vélt vagy valós kapcsolatok közzétevése egészen tág teret enged az átlag hírolvasó, -hallgató, -néző képzeletének - különsen akkor, ha kcsit is fogékony a téma iránt.

\section{Forrás: sci-fi történet}

A népszerű tudományos-fantasztikus filmet, a „Harmadik típusú találkozások”at (aminek „Close Encounters of the Third Kind" az eredeti címe), a 1977-ben mutatták be az USA-ban, és azóta világszerte kultuszfilm lett (3. ábra). A mú hatalmas nézőseregnek mutatta be nem csak azt, hogy egy másik bolygó lényei hogyan nézhetnek ki, miként viselkedhetnek, mi 
3. ábra: A Harmadik típusú találkozások c. film posztere (Spielberg, 1977)

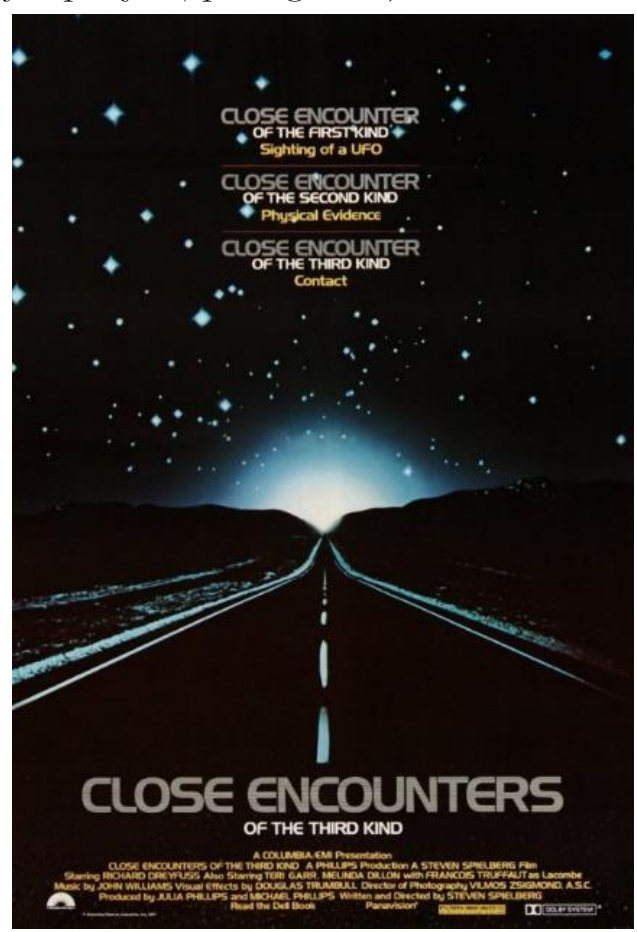

lyen technikai eszközeik lehetnek, hanem azt is, hogy a (főként: USA-beli) kormányzati szervek hogyan kísérelnék meg titokban tartani saját állampolgáraik előtt is az esetet.

Steve Lewis (idézi Martinez, 2006) a légierő hírszerzésnek korábbi tisztviselője kijelentette, hogy: „A Harmadik típusú találkozások című film sokkal valóságosabb, mint hinnék. Akár hiszik, akár nem."

Az 1977-ben megjelent film forgatókönyvírója és egyben rendezője, Steven Spielberg pedig saját bevallása szerint akkor kezdett el igazán hinni a történetben, amikor megtudta, hogy a kormány a film ellen van. A közismert rendező egy nyilatkozatában megjegyezte (idézi Kasten, 2007): „Ha a NASA időt fordított rá, hogy huszonkét oldalas levelet írjon nekem, akkor ott biztosan történik valami." Spielberg a film kapcsán privát találkozáson vehetett részt a projektről vélhetően felvilágosított Reagan elnökkel a Fehér Házban (Martinez, 2006).

\section{Forrás(?): elnökök, tisztek és tudósok}

„A felét sem tudjátok...” - ez az összes, amit elárulhatott az első elnöki választási kampánya idején a korábbi CIA igazgató (Martinez, 2006), George Herbert Walker Bush, az USA 41. elnöke 1989-1993 között, és aki korábban a már említett Ronald Reagan elnöksége idején alelnök volt. Noha sokan kétségbe vonják a legenda hitelességét, vannak, akik úgy tartják, hogy J. F. Kennedy, 18 hónappal a csereprogram kezdete előtt (tehát 1963-ban), fel akarta tárni az igazságot az űrlényekről, s ez okozta a vesztét (Pilkington, 2006): 1963. november 22-én merénylet áldozata lett.

Paul McGovern védelmi hírszerző állítása szerint 3000 oldalas jelentés készült a küldetésről, képekkel együtt - hivatkozik Ryan (2006) McGovern-re. A nagyközönség az Egyesült Államok kormányának egyik visszavonult alkalmazottja által szerzett tudomást a „Project Serpo”-ról, aki hosszas levelezéseket folytatott a témában Victor Martinez korábbi USA kormányalkalmazottal (Martinez, 2006; Doty, 2006). 
Paul McGovern és Gene Lakes (aka Loscowski, korábbi biztonsági igazgató a Nevada Test Site-nál) rendszeresen ellenőrizte és pontosította ezeket az információkat. Ezenkívül több kutató, tiszt (például Linda Howe, Whitley Strieber) állítja, hogy tud a csereprogram létezésérôl (Ryan, 2006).

A fentebb említett 3000 oldalas jelentés fotói nem kerültek nyilvánosságra. Ryan (2006) azt is beismeri, hogy ha a fotók most kikerülnének, az valószínúleg paradox módon azt sugallná az olvasóknak, hogy meg lettek hamisítva.

\section{Forrás: US Légierō}

Az USA légiereje 1994-ben jelentést adott közre a Roswell-esetról. Ebben azt állítják, hogy az 1947-ben lezuhant objektum valójában a Légierô egy léggömbje volt, amit egy „Project Mogul” nevű titkos programban használtak (Lewis és Swanson, 2009).

A „Project Mogul” az új-mexikói Los Alamos Nemzeti Laboratóriumban valósult meg, azzal a céllal, hogy felderítő (a fedőtörténet szerint: meteorológiai) léggömbök segítségével megfigyeljék a lehetséges szovjet nukleáris aktivitásokat.

A jelentés szerint 1947. június 4-én kilőtték a New York University Flight \#4 léggömböt, ami később szerencsétlen módón lezuhant William Brazel farmján, kirobbantva a híres-hírhedt ,,roswelli incidenst" és az általános ürlény hisztériát (Thomas, 1995; Webster, 2017 - v.ö.: 4. ábra).
4. ábra: a Roswell Incidens okaként megjelölt, a „Project Mogul”-ban alkalmazott meteorológiai léggömbök egyike (forrás: Thomas, 1995)

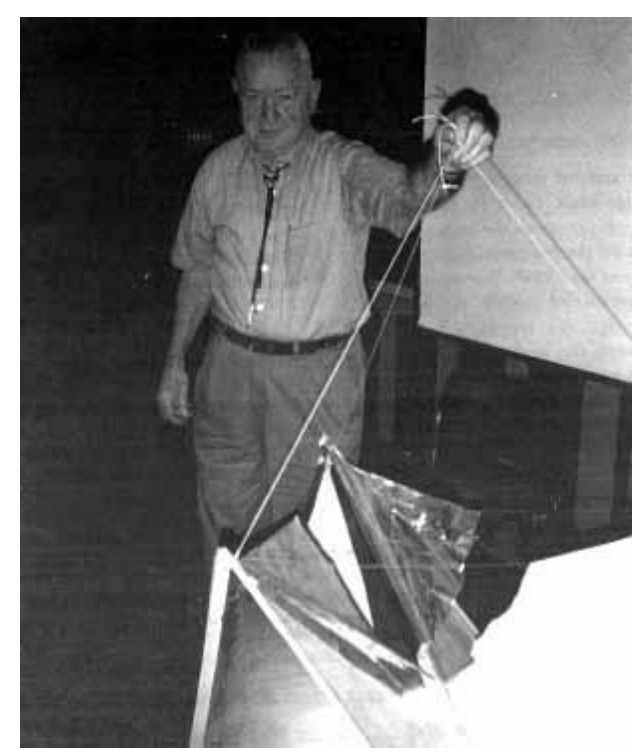

E megközelítés szerint: mivel sose zuhant le űrhajó Roswellben, ezért nem is jöhetett létre az eddig említett „Project Serpo".

Az összeesküvés elméletek kreálóinak várható természetes reakciója Ryan (2006) alapján: a katonai jelentésben szereplő léggömb csak kitalált fedőtörténet, ami a „valóság” leplezésére és a tömegek megtévesztésére szolgál...

\section{Forrás: Serpo.org}

$\mathrm{Az}$ átfogóbb kép érdekében Bill Ryan 2005-ben létrehozta a serpo.org weboldalt, ahol az érdeklődők részletesebb in- 
formációkat kaphatnak a projektrôl. Az oldal kitér arra is, hogy az US kormányzati szervek állítólag milyen különböző módokon próbálták a témával kapcsolatos kutatásokat leállítani. Összegyűjtötte a témában megjelent cikkeket, amik választ adnak arra a kérdésre is, hogy miért nem a CNN-t vagy más nagyobb hírportált kerestek meg a „Project Serpo” történet hívői. A magyarázatban felvetett indoklás egyszerű: elnöki beleegyezésre lenne szükség ahhoz, hogy a nagy hírügynökségek leadják az igazságot. Viszont Kennedy óta akárhány elnök került is kapcsolatba ezzel a projekttel, egyikük sem vállalta, hogy elvágja a politikai karrierjét a „Project Serpo"-val kapcsolatos kijelentésekkel (Martinez, 2006).

\section{Forrás: Mirage Men}

Míg a korábbi összeesküvéselméletek arra vonatkoztak, hogy az amerikai kormány igyekszik meghiúsítani a „serpo Project"-re vonatkozó kutatásokat és tudósításokat, addig a „Mirage Men” alkotói új fordulatot hoztak a legenda alakulásába.

John Lundberg (2013) és két társrendezője által készített „Mirage Men” című dokumentumfilmként bemutatott alkotás (Mark Pilkington 2010-ben kiadott ugyanezt a nevet viselő könyvére alapozva) azt mutatja be, hogy az amerikai kormány, hogyan alakította ki az űrlény mítoszt tudatosan, mint egy fedőtörténetként alkalmazva (lásd: 5. ábra).
5. ábra: Mirage Men címü film plakátja (forrás: Lundberg, 2013)

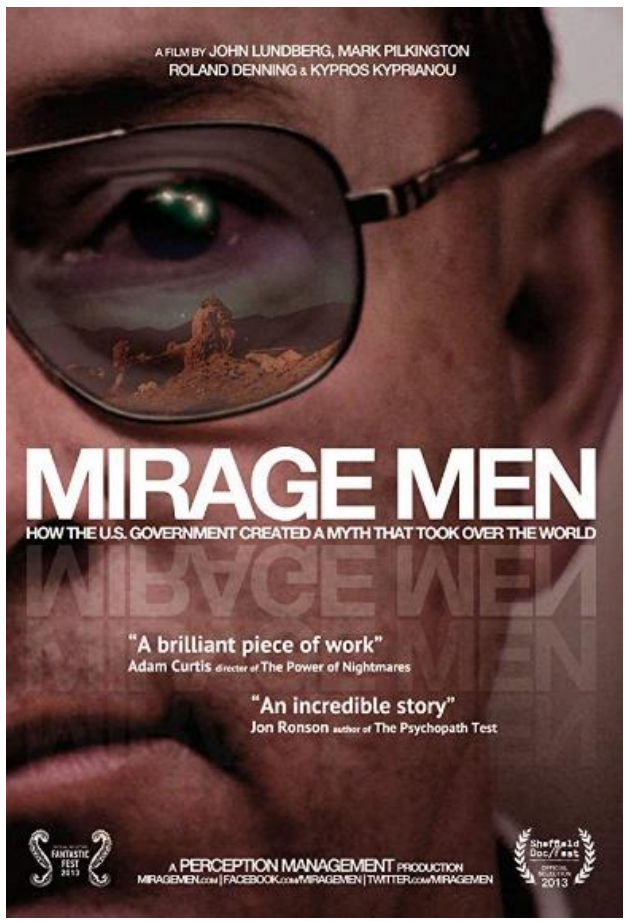

A filmben a „Serpo Project” történetének több fontos szereplője ad interjút például: Richard Doty (aki a film egyik fő karaktere), Victor Martinez, Bill Ryan.

A film Bob Durant (2013) monológjával kezdődik, aki Dotyt professzionális félretájékoztatónak és hazugságra kiképzettnek nyilvánítja. Közvetlen ezután Doty (2013) szintén beismeri, hogy a kormánynak végzett munkája során, tudatosan nem egyszer félrevezette az embereket UFO történetekkel. Állítása szerint az esetek többségében az űrlényekrôl küzreadott infor- 
máció 80\%-a hamis, azonban ezt a közönség nem tudja kiszűrni.

A dokumentumfilm válaszként arra, hogy a kormány, miért fordul ilyen eszközökhöz, azt adja, hogy ha az emberek UFO történetei miatt titokban marad a katonai, technikai fejletség a mindenkori ellenséggel szemben, akkor nem elfojtani, hanem szítani kell a tüzet. Legendát kell kreálni! A film szerint tehát az amerikai kormánynak köze van a roswelli incidensből kialakult UFO mitológia létrejöttében.

A „Project Serpo” azonban itt is sok találgatásra ad okot. Doty (2013) állítja, hogy „sok információ, nem az összes különleges információ, de sok információ tényeket tartalmaz". Victor Martinez (2013) azt nyilatkozta a filmben, hogy amikor először kapott Anonymustól (titkos hírforrásától) e-mailt, abban egy másik verziója volt egy történetnek, ami számára ismerős volt.

$\mathrm{Az}$ igazi gondot valójában Richard Doty - aki a volt munkája során köztudott szélhámos volt az UFO közösségben - szerepe okozza. Doty (2013) és Martinez (2013) ugyanakkor állítja, hogy Dotynak semmi köze nem volt a „Project Serpo"-hoz. Stephen Broadbent (2013) viszont a Victor Martinezzel folytatott együttműködésük során kutatócsapatával azt fedezte fel, hogy Anonymus és más ismeretlen emberek, akik Martineznek írtak a témában, ugyanazt az IP címet használták, amit Doty is.

Ez arra enged következtetni, hogy Richard Doty áll az egész történet mögött, ami Doty embereket félreinformáló történetei miatt, nem lenne meglepő.

Egy másik érdekesség, amit a „Mirage Men" című film mutat be Dotyról, hogy hiába tagadja folyamatosan, hogy semmi köze a „Project Serpo”-hoz, mégis elment arra az UFO konferenciára, ahol élóben hallgathatta meg Bill Ryan beszédét. Bill Ryan (2013) a történet kormány oldaláról annyit nyilatkozik a filmben, hogy biztos benne, hogy megfigyelik.

A film egyik legnagyobb kérdése, hogy (Howe, 2013): mi lehet olyan fenyegetô (és itt nem az űrlények fenyegetésére célozva), amit a kormány - és nem a légierô stb., hanem kifejezetten az amerikai kormány - ilyen kétségbeesetten eltitkol, hogy a földönkívüli történetek használatához folyamodik?

Azt is észrevehetjük a film nézése közben, hogy csak a Légierő támogatja az UFO történeteket, a média úgy tartja, hogy az UFO hívő emberek csak túl sok mozifilmet láttak.

Ugyanakkor a „Mirage Men”-ben is említik, a kormány, a Légierő, a CIA stb. alkalmazottai között vannak, akik tényleg elhiszik ezeket a történeteket és mivel ranggal rendelkeznek, a véleményük maga bizonyítéknak számít (Lundberg, 2013).

\section{A legendában nem bivōk \\ által terjesztett legendák}

A történetben kételkedők között megjelent az a híresztelés is, hogy a „Serpo Project” alapját képező történetbeli űreszköz 
egy prototípus volt kifejezetten arra kitalálva, hogy tesztelje és kalibrálja a korabeli számítógépes megfigyelő programokat (Junkie, 2018).

Azt is érdekes megfigyelni, hogy minden cikkben csereprogramként hivatkoznak a projektre. Ennek ellenére csak a Serpo bolygóra eljutott űrhajósokról írnak. Pedig a csereprogram névből adódik, hogy a Földön is maradtak EBE-k, akikről nem tudni semmit. Ilyen alapon a kellően empatikus médiafogyasztók joggal aggódhatnak azon is, hogy a Földre eljutott EBE-k otthon maradt rokonai, milyen aggodalmakat élhettek, élhetnek át szeretteik miatt. Természetesen azon is elmorfondírozhatnak, hogy az EBEmédia miként tárgyalja a „Project Earth” (Föld Projekt) esetét, s milyen legenda szövődhet a földlakókkal kapcsolatban a Serpo bolygón, miközben annak két napja barátságos fénybe vonja a tájat.

\section{Összegzés}

A UFO történetek egyik „legbájosabb” és egyben legizgalmasabb vonása, hogy átlagemberként, -olvasóként, média fogyasztóként nem lehet azokat ellenőrizni.

A „Project Serpo” történetnek, mint a legendáknak általában, lehet némi (űrlényeket és csillagközi utazást nem feltételező) valóságalapja. Mint Bill Ryan (2007) megjegyzi a serpo.org oldalon tett utolsó bejelentkezésekor: „Hiszem, hogy a Serpo történet félretájékoztatások (azaz az igazsághoz kevert kitalált elemek) és természetesen előforduló hibák (mint a csapat parancsnoki naplójának kijavítatlan hangszalag másolatai) keveréke... amik körülveszik a rendkívüli és alapvető igazságot."

A „Project Serpo” egy csavaros, titkokkal átszőtt történet, amit a média közvéleményt befolyásoló szerepe, valamint az olyan emberi tényezôk tesznek igazán különlegessé, mint a kíváncsiság, a fantázia, a bizalmatlanság és félelem. A történet tanulsága az is, hogy az átlag médiafogyasztók milliárdjai vannak kitéve nap, mint nap az általuk nehezen ellenőrizhető hírözönnek, illetve Kenyeres (2014) szavaival élve: a „médiamanipuláció boszorkánykonyhájának".

\section{Irodalom:}

Birnes, Williams (2006): Article 1. UFO Magaz̧ine. Letöltés: 2019.09.18. Web: http://serpo.org/article1.php

Broadbent, Stephen (szereplő, 2013): Mirage Men (film). Perception Management Productions, London.

Doty, Richard (2006): Project Serpo. UFO Magaz̧ine. Letöltés: 2019.09.18. Web: http://www.ufoconspiracy.com/repor ts/doty-rick-serpo.pdf

Doty, Richard (szereplő, 2013): Mirage Men (film). Perception Management Productions, London.

Durant, Bob (szereplő, 2013): Mirage Men (film). Perception Management Productions, London.

Gaia (2017): Project Serpo And The Zeta Reticuli Exchange Program. Letöltés: 2019.09.17. Web: https://www.gaia. 
com/article/project-serpo-zeta-reticu li-exchange-program

Howe, Linda (szereplő, 2013): Mirage Men (film). Perception Management Productions, London.

Junkie, Red Pill (2018): The Serpo and the Apple. Letöltés: 2019. 11.16. Web: https://mysteriousuniverse.org/2018/ 04/the-serpo-and-the-apple/

Kasten, Len (2007): Article 6. Atlantis Rising 61. Letöltés: 2019.09.18. Web: http://serpo.org/article6.php

Kasten, Len (2013): Secret Journey to Planet Serpo: A True Story of Interplanetary Travel. Rochester (VT): Bear \& Company.

Kenyeres Attila Zoltán (2014): A médiamanipuláció boszorkánykonyhája. Magánkiadás, Debrecen.

Lewis, Marieke és Swanson, Ryan (2009): Astronautics and Aeronautics: A Chronology, 1996-2000 (NASA SP2009-4030). Washington (USA): NASA Headquarters, p. 77.

Lundberg, John (rendező, 2013): Mirage Men (film). Perception Management Productions, London.

Lundberg, John (2013): Mirage Men c. film boritója. Letöltés: 2019.11.16. Web: https://www.imdb.com/title/tt22540 10/mediaviewer/rm4167097856

Martinez, Victor (2006) Article 2. UFO Magażine. Letöltés: 2019.09.18. Web: http://serpo.org/article2.php

Martinez, Victor (szereplő, 2013): Mirage Men (film). Perception Management Productions, London. Pilkington, Mark (2006): Article 5. Fortean Times
209. Letöltés: 2019.09.18. Web: http://serpo.org/article5.php

Net1: Világ - népesség 1800-2100. Letöltés: 2020.04.08. Web: http://nepesseg. population.city/world

Net2: Településtípusok - Térport. Lechner Nonprofit Kft., Budapest. Letöltés: 2020.04.8. Web: http://www.terport. hu/telepulesek/telepulestipusok

Roswell Daily Record, 1947.07.08., p.1. Letöltés: 2019.09.17. Web: https:// toome.news/2018/how-ufo-sightingsparked-70-years-of-conspiracytheories/

Ryan, Bill (2006) UFO Magazine. Letöltés: 2019.09.18. Web: http://serpo.org/ article4.php

Ryan, Bill (2007): A Final Update from Bill Ryan: 5 March 2007. Letöltés: 2019.09.18. Web: http://serpo.org/ final_update.php

Ryan, Bill (szereplő, 2013): Mirage Men (film). Perception Management Productions, London.

Spielberg, Steven (rendező, 1977): Harmadike típusú találkozások posżter. IMDB. Letöltés ideje: 2019.12.05. Web: https://www.imdb.com/title/tt00758 60/mediaviewer/rm2586827008

Swartz, Tim (2007): Project Serpo: Fact or Fiction? Atlantis Rising 61. Letöltés: 2019.09.18. Web: http://www.zaman dayolculuk.com/html-2/projectserpo. htm

The Sacramento Bee, 1947.07.08., p.1. Letöltés: 2019.09.17. Web: https://upload. wikimedia.org/wikipedia/commons/2 
/25/SacramentoBeeArticleJuly8\%2C1 947.jpg

Thomas, Dave (1995): The Roswell Incident And Project Mogul. Special Report, Volume 19, No.4. Letöltés: 2019.11.05. Web: https://skeptical inquirer.org/1995/07/the_roswell_inc ident_and_project_mogul/
Webster, Donovan (2017): In 1947, A High-Altitude Balloon Crash Landed in Roswell. The Aliens Never Left. Smithsonian. Letöltés: 2019.11.05. Web: https://www.smithsonianmag. com/smithsonian-institution/in-1947high-altitude-balloon-crash-landedroswell-aliens-never-left-180963917/ 